\title{
MICROBIAL OILS AND FATTY ACIDS: EFFECT OF CARBON SOURCE ON DOCOSAHEXAENOIC ACID (C22:6 N-3, DHA) PRODUCTION BY THRAUSTOCHYTRID STRAINS
}

\author{
C. Shene ${ }^{1 *}$, A. Leyton ${ }^{1}$, Y. Esparza ${ }^{1}$, L. Flores ${ }^{1}$, B. Quilodrán ${ }^{2}$, I. Hinzpeter ${ }^{3}$ and \\ M. Rubilar'. \\ ${ }^{1}$ Center of Food Biotechnology and Bioseparations BIOREN and Agri aquaculture Nutritional \\ Genomic Center. Technology and Process Unit, Universidad de La Frontera, Casilla 54-D, \\ Temuco, Chile. ${ }^{2}$ Department of Natural Resources and Environment, Universidad de Los Lagos, \\ Casilla 557, Puerto Montt, Chile. ${ }^{3}$ Department of Government and Management, Universidad de \\ Los Lagos, Casilla 557, Puerto Montt, Chile.*Corresponding author: cshene@ufro.cl
}

\begin{abstract}
Thraustochytrids are marine protists found throughout the world in estuarine and marine habitats. These microorganisms have attracted interest, because their lipids contain different long chain polyunsaturated fatty acids (PUFAs). Those able to produce docosahexaenoic acid (C22:6 n-3, DHA) are the most studied because of the physiological importance of this PUFA in human beings. Their heterotrophic cultivation offers several challenges since biomass, lipid content, and fatty acid profile are dependent on growth conditions. In this work the effects of $\mathrm{C}$ source and its concentration on DHA production by different thraustochytrid strains are reviewed. Results obtained by different investigators on the use of alternative and low cost nutrient sources for production of DHA by thraustochytrids are also presented.
\end{abstract}

Keywords: Thraustochytrium, Schizochytrium, docosahexaenoic acid, polyunsaturated fatty acids, lipids, carbon source, nitrogen source.

\section{INTRODUCTION}

Docosahexaenoic acid (C22:6 n-3, DHA), a highly unsaturated long chain fatty acid, is a major structural component in neural tissues and retina. It is considered essential for infants' nutrition, because it is involved in brain development. Dietary DHA has positive effect on several diseases such as hypertension, arthritis, atherosclerosis, depression, adult-onset diabetes mellitus, myocardial infarction, thrombosis, and some cancers (Horrocks and Yeo, 1999).

At present time, fatty fish from cold marine waters and fish oils are the main sources of DHA. In fish oils, both composition and quantity of polyunsaturated fatty acids (PUFAs) depend on the species, and time and geographical location of the capture. In addition, conditions of processing and refining can affect the quality of PUFAs in fish oils. PUFAs are naturally found with cis isomery (over 95\%) to which all metabolic and structural functions are related.

Fish, just like human beings, have a low capability to synthesize long chain PUFAs, such as DHA, and rely on 
phytoplankton, autotrophic bacteria and components in the zooplankton to obtain these molecules (Iwamoto and Sato 1986). Several species of marine bacteria, especially those found in cold and high pressure environments, accumulate lipids with high percentages of eicosapentaenoic acid (C20:5 n-3, EPA) and DHA (Nichols et al., 1993). Profile of the fatty acids synthesized by marine bacteria is very simple unlike the complex mixture found in fish oils and oils accumulated by phototrophic microalgae; the disadvantage of this microbial PUFA source is its low lipid yield (Nichols et al., 2002). Higher contents of PUFAs have been found in the biomass of different thraustochytrid strains isolated from estuarine and marine habitats throughout the world.

Thraustochytrids are marine protists that have been classified into the class Labyrinthulomycetes, a phylogenetic group in the stramenopile organisms, which consists of two well accepted families, i.e., Labyrinthulaceae and Thraustochytriaceae (Honda et al., 1999; Leipe et al., 1994; Porter, 1989). The Thraustochytriaceae family is composed of seven genera: Thraustochytrium, Schizochytrium, Ulkenia, Labyrinthuloides, Japonochytrium, Aplanochytrium and Althornia (Porter, 1989). Combination of morphological and chemotaxonomic features such as PUFA profiles and carotenoid pigments can be used to distinguish at genus-level phylogenetic groups in the Labyrinthulomycetes (Yokoyama et al., 2007; Yokoyama and Honda, 2007). Six different PUFA profiles have been reported in thraustochytrids (Huang et al., 2003; Burja et al., 2006). These are: (1) DHA and docosapentaenoic acid (DPA, C22:5 n-6); (2) DHA, DPA, and EPA; (3) DHA and EPA; (4) DHA, DPA, EPA, and arachidonic acid (ARA, C20:4 n-6); (5) DHA, DPA, EPA, ARA, and docosatetraenoic acid (DTA, C22:4 n-6); and (6) DHA, EPA, and ARA.

Products described in this microorganisms include $\beta$-carotene, astaxanthin and canthaxanthin (Aki et al., 2003), squalene, a precursor of phytosterols (Jiang et al., 2004; Fan and Chen, 2007), phospholipids (Okuyama et al., 2007), sterols, and sulfated extracellular polysaccharides (Jain et al., 2005). Although all these products are demanded by pharmaceutical and food industries the most valued is DHA. This long chain PUFA is found in storage lipids, and cell membrane phospholipids in thraustochytrid cells (Morita et al., 2006). Up to now it is not clear why these protists produce DHA as storage lipids, although it is believed that this fatty acid is crucial for their survival. Some researchers suggest that lipids serve as energy source for displacement and for the production of ectoplasmatic nets. Although DHA is preferentially used as energy source under starving conditions, the PUFAs could also protect cells from oxidative stress when nutrients are depleted, because of their antioxidant properties. In addition, cells with higher PUFA contents are gravitationally less dense than those containing more saturated fatty acids, a difference that could induce displacement to nutrient-rich environments (Jain et al., 2007).

Because of the industrial and commercial interest originated from recent discoveries of physiological DHA importance in human beings, animals and fish, thraustochytrids are currently objects of study, and characteristics of new strains are periodically reported. At present, two isolates, Schizochytrium sp. 20888 and Ulkenia sp., are being exploited for commercial DHA production (Barclay et al., 2005; Kiy et al., 2005).

DHA content in thraustochytrid cells is strongly dependent on environmental 
factors such as temperature, salinity, and culture medium composition. Thraustochytrids are able to grow on different organic $\mathrm{C}$ sources and both organic and inorganic $\mathrm{N}$ sources (Goldstein, 1973); nevertheless, the composition of growth medium also influences biomass production and lipid composition, thus DHA yield is also affected. This work reviews the effects of $\mathrm{C}$ source on DHA production by different thraustochytrid strains. Results obtained by different investigators on the use of alternative and low cost nutrient sources for DHA production by thraustochytrids are also presented. Finally, results obtained in the production of DHA by thraustochytrids under different cultivation strategies were described.

Effect of medium composition on DHA production by different thraustochytrid strains

For the cultivation of different thraustochytrid strains, glucose is generally the first $\mathrm{C}$ source evaluated. On the other hand, organic (yeast extract, tryptone, polypeptone) and inorganic (ammonium sulfate, ammonium chloride) $\mathrm{N}$ sources have been tested at different concentrations, because the $\mathrm{C} / \mathrm{N}$ ratio influences lipid accumulation in some strains. Lipid accumulation, in oleaginous microorganisms, occurs when the medium contains a $\mathrm{C}$ source excess and a limiting $\mathrm{N}$ amount. Thus, when the organism grows, it quickly exhausts $\mathrm{N}$ source but it continues assimilating the $\mathrm{C}$ source that is channeled directly into lipid synthesis (Ratledge and Wynn, 2002). However, cultural conditions involving low $\mathrm{N}$ concentrations decrease cell growth, hence, lower lipid and DHA yields are obtained.

One of the first strains evaluated for the production of DHA was T. aureum ATCC 34304. Lipid content in the biomass of this microorganism was dramatically influenced by the medium composition (concentrations of glucose, organic $\mathrm{N}$ source, vitamins and salts) (Bajpai et al., 1991). An increase of glucose concentration from 5 to $20 \mathrm{~g} \mathrm{~L}^{-1}$ increased both the percentage of lipids in the biomass (from 2.7 to $16.5 \%$ ) and DHA yield (from 26 to $270 \mathrm{mg} \mathrm{L}^{-1}$ ) in a 6-day incubation.

Growth and DHA production by $T$. roseum ATCC28210 in media containing starch $\left(25 \mathrm{~g} \mathrm{~L}^{-1}\right)$ as $\mathrm{C}$ source was studied by Singh and Ward (1996); ammonium sulfate $\left(0.2 \mathrm{~g} \mathrm{~L}^{-1}\right)$, and sodium glutamate $\left(2 \mathrm{~g} \mathrm{~L}^{-1}\right)$ were used as $\mathrm{N}$ sources. Biomass and DHA yields of $6.1 \mathrm{~g} \mathrm{~L}^{-1}$ and $528 \mathrm{mg}$ $\mathrm{L}^{-1}$, respectively, were obtained after 5 days. Growth medium supplemented with yeast extract $\left(2 \mathrm{~g} \mathrm{~L}^{-1}\right)$ allowed to increase biomass and DHA yields to $8.6 \mathrm{~g}$ of dry cell weight (DCW) per $\mathrm{L}$ and $892 \mathrm{mg} \mathrm{L}^{-1}$, respectively. The increase of $\mathrm{KH}_{2} \mathrm{PO}_{4}$ concentration from $0.1 \mathrm{~g} \mathrm{~L}^{-1}$ to $0.2 \mathrm{~g} \mathrm{~L}^{-1}$ improved DHA yield by $40 \%$, whereas a reduction in $\mathrm{NaCl}$ concentration (from 25 $\mathrm{g} \mathrm{L}^{-1}$ to $10 \mathrm{~g} \mathrm{~L}^{-1}$ ) had no effect on DHA yield. Attempts to increase biomass and DHA yields were made by supplying additional doses of carbohydrate equivalent to $10 \mathrm{~g} \mathrm{~L}^{-1}$ after both 4 and 6 days in a fed-batch system. This cultivation condition increased dramatically biomass yield, and the contents of lipid and DHA in the biomass. Maximum biomass (12.1 $\left.\mathrm{g} \mathrm{L}^{-1}\right)$, lipid in biomass $(23.7 \%)$, and DHA in biomass (118 $\mathrm{mg} \mathrm{g}^{-1}$ ) were obtained after 8 days; final DHA yield was $1433 \mathrm{mg} \mathrm{L}^{-1}$. The same process carried out supplying glucose instead of starch resulted in a lower DHA yield $\left(1130 \mathrm{mg} \mathrm{L}^{-1}\right)$. In a fedbatch fermentation carried out for 12 days adding aliquots containing starch $(10 \mathrm{~g}$ $\left.\mathrm{L}^{-1}\right)$, sodium glutamate $\left(0.8 \mathrm{~g} \mathrm{~L} \mathrm{~L}^{-1}\right)$, ammonium sulfate $\left(0.08 \mathrm{~g} \mathrm{~L}^{-1}\right), \mathrm{KH}_{2} \mathrm{PO}_{4}$ $\left(0.08 \mathrm{~g} \mathrm{~L} \mathrm{~L}^{-1}\right)$ and $\mathrm{MgSO}_{4} \quad\left(2 \mathrm{~g} \quad \mathrm{~L}^{-1}\right)$ maximum biomass and DHA yields were 
$17.1 \mathrm{~g} \mathrm{~L}^{-1}$ and $2 \mathrm{~g} \mathrm{~L}^{-1}$, respectively. These results indicate that biomass growth and DHA production can be increased by feeding not only the $\mathrm{C}$ source but also the $\mathrm{N}$ sources and salts.

Conditions for DHA production at a high level by Schizochytrium sp. SR21 through changes in the composition of the growth medium were reported by Yaguchi et al. (1997). With medium I [glucose $60 \mathrm{~g} \mathrm{~L}^{-1}$, corn steep liquor $0.7 \mathrm{~g}$ $\mathrm{L}^{-1}$, ammonium sulfate $2 \mathrm{~g} \mathrm{~L}^{-1}, \mathrm{KH}_{2} \mathrm{PO}_{4} 3$ $\mathrm{g} \mathrm{L}^{-1}$, in $50 \%$ artificial sea water (ASW)] strain SR21 produced $21.9 \mathrm{~g} \mathrm{DCW} \mathrm{L}^{-1}$ and $5.1 \mathrm{~g} \mathrm{DHA} \mathrm{L}^{-1}$ at $65 \mathrm{~h}$. By increasing twice $\mathrm{C}$ and $\mathrm{N}$ amounts, higher biomass (48.1 $\mathrm{g} \mathrm{L}^{-1}$ ) and DHA (13.3 $\mathrm{g} \mathrm{DHA} \mathrm{L}^{-1}$ ) yields were obtained at $96 \mathrm{~h}$. It was possible to produce $59.2 \mathrm{~g} \mathrm{DCW} \mathrm{L}^{-1}$ and $15.5 \mathrm{~g} \mathrm{DHA} \mathrm{L}^{-1}$ in the fermentation of a medium that contained glucose $150 \mathrm{~g} \mathrm{~L}^{-1}$, corn steep liquor $1.75 \mathrm{~g} \mathrm{~L}^{-1}$, ammonium sulfate $5 \mathrm{~g} \mathrm{~L}^{-1}$. Lipid content in the cells of strain SR21 increased with cell growth. In the early growth phase, neutral and polar lipids were produced in about equal amounts; however after this phase the content of neutral lipids increased with cell growth. In the stationary growth phase lipid profile became $95 \%$ neutral lipids and 5\% polar lipids. Neutral lipids were composed of $35 \%$ DHA and $6 \%$ DPA while the content of these fatty acids in polar lipids was $63.5 \%$ and $24.7 \%$, respectively.

The biomass, lipid and DHA production by strain G13, a thraustochytrid strain resembling Schizochytrium mangrovei, was evaluated in a medium that contained glucose $(40 \mathrm{~g}$ $\left.\mathrm{L}^{-1}\right)$, yeast extract $\left(20 \mathrm{~g} \mathrm{~L}^{-1}\right)$, and ASW (27 $\mathrm{g} \mathrm{L} \mathrm{L}^{-1}$ ) (Bowles et al., 1999). Maximum biomass yield $\left(14 \mathrm{~g} \mathrm{~L}^{-1}\right)$ was reached at $41 \mathrm{~h}$, close to the point of glucose exhaustion. This was also the point at which the lipid content in the biomass reached a maximum of $56 \%$ $(w / w)$. The DHA content in the lipids remained stable at around $28 \%(\mathrm{w} / \mathrm{w})$ from 63 to $120 \mathrm{~h}$ cultivation. Composition of the medium was modified further by substituting the ASW with sodium sulphate $\left(20 \mathrm{~g} \mathrm{~L}^{-1}\right)$ as source of sodium, and decreasing the concentration of yeast extract (from 20 to $5 \mathrm{~g} \mathrm{~L}^{-1}$ ). In this modified growth medium glucose was exhausted at $24 \mathrm{~h}$, point at which biomass yield was $14 \mathrm{~g} \mathrm{~L}^{-1}$. At $41 \mathrm{~h}$ the content of lipids in the cells was maximal $(78 \%$ $\mathrm{w} / \mathrm{w}$ ) and the percentage of DHA in the lipids was $18 \%$. A prolonged incubation allowed to increase DHA yield; maximum DHA yield equal to $2.17 \mathrm{~g} \mathrm{~L}^{-1}$ was achieved at $107 \mathrm{~h}$.

A culture medium contained glucose (30 $\left.\mathrm{g} \mathrm{L}^{-1}\right)$, yeast extract $\left(5 \mathrm{~g} \mathrm{~L}^{-1}\right)$, and polypeptone $\left(15 \mathrm{~g} \mathrm{~L}^{-1}\right)$ in $\mathrm{ASW}(50 \%)$ was used for the cultivation of Schizochytrium limacinum KH105, strain that in addition to produce DHA is also able to synthesize carotenoids (Aki et al., 2003). A semi-optimized growth condition, in a baffled flask, yielded 11.5 $\mathrm{g}$ DCW L $\mathrm{L}^{-1}, 5.3 \mathrm{~g}$ of total fatty acids (TFA) per L, and $1.2 \mathrm{~g} \mathrm{DHA} \mathrm{L}^{-1}$ after 2 days. In addition to glucose, strain KH105 was also able to assimilate D-fructose, glycerol, and L-arabinose. This assimilation profile is distinct from those of other Schizochytrium strains; for instance, S. aggregatum ATCC 28209 can propagate in a medium containing maltose or cellobiose, but not D-fructose as a sole C source (Bahnweg 1979).

Schizochytrium sp. F26-b, a strain isolated from Ishigaki island in Japan, produced $3.5 \mathrm{~g} \mathrm{CDW} \mathrm{L}^{-1}$ and $915 \mathrm{mg}$ of lipids $\mathrm{L}^{-1}$ when it was inoculated into a medium containing glucose $(3 \%)$, yeast extract (1\%) in 50\% ASW, pH 6.0 (Abe et al., 2006). The fractions of neutral lipids, glycolipids, and phospholipids corresponded to $66 \%, 7 \%$, and $22 \%$, respectively. The major fatty acids in the total lipid fraction were pentadecanoic acid (C15:0) and DHA; together they 
represented more than $67.1 \%$ of all the fatty acids. The highest proportion of DHA was found in the phospholipid fraction, in which DHA was about $50 \%$ of the fatty acids.

Schizochytrium sp. ONC-T18, isolated from mangrove leaves collected at Advocate Harbour, Nova Scotia, was selected by Burja et al. (2006) for culture optimization. This strain has a high biomass production rate, $25 \%$ higher than that exhibited by Schizochytrium sp. ATCC 20891; moreover this strains is able to accumulate up to $80 \%$ of its biomass as lipid when it was cultivated in a media containing glucose $\left(60 \mathrm{~g} \mathrm{~L}^{-1}\right)$, yeast extract $\left(2 \mathrm{~g} \mathrm{~L}^{-1}\right)$ and monosodium glutamate $\left(8 \mathrm{~g} \mathrm{~L}^{-1}\right)$ with sea salts at $6 \mathrm{~g} \mathrm{~L}^{-}$ 1 . Glucose, DL-malic acid, D-fructose, Dxylose, fumaric acid, D-cellobiose, pyruvic acid, $\alpha$-D-lactose, 5-keto-Dgluconic acid, and glycerol supported good cell growth and DHA yield. A high content of DHA (more than 20\%) in the biomass was obtained with these $\mathrm{C}$ sources. In contrast, di- and polysaccharides gave poor cell growth.

\section{Alternative sources of nutrients for the production of DHA by thraustochytrids}

A favorite substrate for thraustochytrids is Pinus pollen that is often used for their isolation. The pollen wall is impregnated with sporopollenin, a polymeric material composed of oxidized carotenoids and carotenoid esters, which is extremely resistant to acid and alkali attack. It has been suggested that the ability of thraustochytrids to break down sporopollenin walls together with chitin and cellulose could be due to a long evolutionary history or a very specialized adaptation (Chamberlain and Moss, 1988).

Various kinds of alternative $\mathrm{C}$ and organic $\mathrm{N}$ sources were used to investigate the cell growth and DHA yield of S. limacinum SR21 (Yokochi et al., 1998). Compared with glucose, oleic acid and linseed oil gave similar yields of biomass (more than $12 \mathrm{~g} \mathrm{~L}^{-1}$ ) and total fatty acids (more than $2.5 \mathrm{~g} \mathrm{~L}^{-1}$ ). However, the DHA content in the biomass grown in these $\mathrm{C}$ sources was lower than $10 \%$. Best $\mathrm{N}$ source for the production of fatty acids was corn steep liquor; the ratio of total fatty acid content to biomass with corn steep liquor was twice as much as that obtained with yeast extract, the most used $\mathrm{N}$ source for the cultivation of thraustochytrids. Little differences in fatty acid composition were found when corn steep liquor was used instead of yeast extract as $\mathrm{N}$ source; however, the highest DHA yield $(1.7 \mathrm{~g} \mathrm{~L}$ $\left.{ }^{1}\right)$ was obtained with corn steep liquor. The higher accumulation of lipids in the biomass grown with corn steep liquor compared with that obtained with yeast extract was attributed to the lower nitrogen level $(5.5 \%)$ in corn steep liquor compared with the one found in yeast extract $(10 \%)$. Thus, the more $\mathrm{N}$ limiting condition provided by the growth medium that contained corn steep liquor would explain the higher lipid accumulation.

A residue from soymilk production denominated okara was evaluated as nutrient source for the growth of different thraustochytrid strains by Fan et al. (2001). Okara is nutritionally rich, with $52 \%$ carbohydrate, $27 \%$ protein and $12 \%$ fats (Ma et al., 1997). The okara medium was composed of $10 \mathrm{~g}$ of pulverized okara and $1 \mathrm{~L}$ of $15 \%$ ASW at pH 6 . DHA yield in the okara medium was much lower (35.3-72.1 $\mathrm{mg} \mathrm{L}^{-1}$ ) when compared with the yields obtained in a glucose-yeast extract medium (747.7-2778.9 $\left.\mathrm{mg} \mathrm{L}^{-1}\right)$. Composition of the growth medium affected significantly the fatty acid profile of the mangrove thraustochytrid strains; while main fatty acids in cells grown in the glucose medium were palmitic acid and DHA, the cells grown in the okara 
medium contained more oleic and linoleic acids. The authors attributed the observed differences to the fact that simple sugars, such as glucose, are more readily utilizable than the recalcitrant polymers, such as the cellulose, available in okara for bioconversion by thraustochytrids.

Wastewater from barley shochu distillery as nutrient source for the growth of Schizochytrium sp. KH105 was evaluated by Yamasaki et al., (2006). The culture medium was prepared by adding various amounts of glucose and artificial sea salts in wastewater followed by $\mathrm{pH}$ adjustment. Due to the poor growth observed in the absence of glucose, the effect of wastewater concentration on the lipid production was examined in the medium containing glucose $\left(80 \mathrm{~g} \mathrm{~L}^{-1}\right)$ and $50 \%$ shochu distillery wastewater at $\mathrm{pH}$ 7.5. Maximum of DHA yield obtained after 4 days was $3.4 \mathrm{~g} \mathrm{~L}^{-1}(25.8 \%$ of the TFA; $115 \mathrm{mg}$ of DHA per $\mathrm{g}$ of cells), which was almost equivalent to the yield obtained in a more expensive culture medium containing polypeptone and yeast extract (Aki et al., 2003).

Crude glycerol, from biodiesel production, was used as $\mathrm{C}$ source for the cultivation of $S$. limacinum SR21 (Chi et al., 2007). Crude glycerol used by these investigators contained $83 \% \quad(\mathrm{w} / \mathrm{w})$ glycerol and $12 \%(\mathrm{w} / \mathrm{w})$ methanol. The used $\mathrm{N}$ sources were tryptone $\left(1 \mathrm{~g} \mathrm{~L}^{-1}\right)$, and yeast extract $\left(1 \mathrm{~g} \mathrm{~L}^{-1}\right)$. Results were compared with those obtained with glucose and pure glycerol. DHA yield and DHA productivity showed similar trends as those exhibited by the CDW. In the fermentations of glucose, pure glycerol and crude glycerol CDW yields were $18.47 \mathrm{~g} \mathrm{~L}^{-1}, 14.43 \mathrm{~g} \mathrm{~L}^{-1}$, and $18.04 \mathrm{~g} \mathrm{~L}^{-1}$, respectively. The effects of crude glycerol concentration on cell growth and DHA production were investigated by including crude glycerol at levels ranging from 75 to $150 \mathrm{~g} \mathrm{~L}^{-1}$ into ASW; growth was inhibited when the crude glycerol concentration exceeded $100 \mathrm{~g} \mathrm{~L}^{-1}$. Under the optimum culture condition $\left(100 \mathrm{~g} \mathrm{~L}^{-1}\right.$ crude glycerol, $19.2^{\circ} \mathrm{C}$ and $1.0 \mathrm{~g} \mathrm{~L}^{-1}$ ammonium acetate), DHA content in the biomass was more than $20 \%$ and DHA yield was $4.91 \mathrm{~g} \mathrm{~L}^{-1}$.

Schizochytrium mangrovei sp. Sk-02 isolated from samples collected in a mangrove forest was used to evaluate the effect of coconut water $(\mathrm{CW})$ in a glucose-yeast extract diluted in sea water medium on DHA yield (Unagul et al., 2007). CW contained a significant amount of monosaccharides in the form of glucose and fructose (total $11 \mathrm{~g} \mathrm{~L}^{-1}$ ), and sucrose $\left(6.7 \mathrm{~g} \mathrm{~L}^{-1}\right)$; together these sugars accounted for almost half of the dry solids in $\mathrm{CW}$ while $\mathrm{N}$ was a minor component. Optimal CW-level was $33 \% \quad(\mathrm{v} / \mathrm{v})$, resulting in a biomass yield of $28 \mathrm{~g} \mathrm{~L}^{-1}$ with a DHA content in the biomass of $20 \%(\mathrm{w} / \mathrm{w})$. DHA yield was $6 \mathrm{~g} \mathrm{~L}^{-1}$, almost 50\% higher than the yield obtained in the non-supplemented cultures at the same initial sugar concentration.

Soybean cake hydrolysate was evaluated as a cheap $\mathrm{N}$ source for the production of DHA by $S$. limacinum OUC88, strain derived from S. limacinum SR21 by UV-mutagenesis (Zhu et al., 2008). Different C sources (glucose, fructose, soluble starch, potato powder and glycerol) were used separately at a concentration of $30 \mathrm{~g} \mathrm{~L}^{-1}$ in the basal medium that contained soybean cake hydrolysate $\left(20 \mathrm{~g} \mathrm{~L}^{-1}\right)$ and $50 \%$ natural seawater. Among the $\mathrm{C}$ sources tested, potato powder yielded the highest biomass concentration $\left(14.05 \mathrm{~g} \mathrm{DCW} \mathrm{L}^{-1}\right)$ while maximum DHA yield $\left(1.78 \mathrm{~g} \mathrm{~L}^{-1}\right)$ was achieved in the glucose containing medium in the presence of soybean cake hydrolysate. This DHA yield was also almost twice as much that obtained with yeast extract. In a further optimization the highest biomass yield (25.92 $\mathrm{g} \mathrm{CDW} \mathrm{L}^{-1}$ ) was observed in the medium containing $90 \mathrm{~g} \mathrm{~L}^{-1}$ of glucose and $60 \mathrm{~g} \mathrm{~L}^{-1}$ soybean 
cake hydrolysate. However, the maximum DHA yield (4.08 $\left.\mathrm{g} \mathrm{L}^{-1}\right)$ was obtained in the medium containing $60 \mathrm{~g} \mathrm{~L}^{-1}$ of glucose and $20 \mathrm{~g} \mathrm{~L}^{-1}$ soybean cake hydrolysate.

Liquid residues from beer $(\mathrm{RB})$ and potato (RP) processing were used as $\mathrm{C}$ sources for the production of DHA by Thraustochytriidae sp. M12-X1 (similar to Thraustochytrium kinnei, $99 \%$ identity) and Thraustochytriidae sp. C41 (similar to Schyzochytrium minutum, 97\% identity) in shaking flasks (Quilodrán et al., 2009). For both strains, RB supplemented with yeast extract and monosodium glutamate, at $2 \mathrm{~g} \mathrm{~L}^{-1}$, permitted the production of the highest biomass concentration $\left(2.3 \mathrm{~g} \mathrm{~L}^{-1}\right)$. In both strains, the relative content of the different fatty acids was significantly affected by the carbon source; fatty acids from cells grown in the media that yielded more biomass contained more palmitic acid. On the contrary, fatty acids from cells grown under limiting conditions contained more DHA. Fermentation of RB medium that contained yeast extract and monosodium glutamate by Thraustochytriidae sp. M12-X1 showed the highest DHA productivity $(55.1 \mathrm{mg}$ $\mathrm{L}^{-1}$ day $^{-1}$ ).

The same residues were used as nutrient sources for cultivating a native Ulkenia strain, able to produce DHA and astaxanthin (Quilodrán et al., 2010). RB, as the only source of nutrients, supported cell growth (8.1 $\left.\mathrm{g} \mathrm{DCW} \mathrm{L}^{-1}\right)$ and DHA production (576 $\mathrm{mg} \mathrm{L}^{-1}$ ); however, its supplementing with yeast extract, monosodium glutamate and B-vitamins (thiamine, biotin and cobalamin) dramatically increased DHA productivity [540 mg L $\mathrm{may}^{-1}$ ] and the yields of biomass (14.9 $\mathrm{g} \mathrm{L}^{-1}$ ) and DHA (2698 mg $\left.\mathrm{L}^{-1}\right)$.

\section{Cultivation strategies for the production of DHA by thraustochytrids}

Ganuza et al. (2008) evaluated the capacity of the $\mathrm{pH}$-auxostat system to optimize growth of Schizochytrium sp. $\mathrm{G} 13 / 2 \mathrm{~S}$, strain derived by nutritional selection from strain G13. The medium contained glucose and ammonia at concentrations of $150 \mathrm{~g} \mathrm{~L}^{-1}$ and $2.4 \mathrm{~g} \mathrm{~L}^{-1}$, respectively. $\mathrm{pH}$-auxostat fermentation was carried out controlling $\mathrm{pH}$ at 7 with $\mathrm{NH}_{4} \mathrm{OH}$; by this strategy ammonia concentration was maintained between $300 \mathrm{mg} \mathrm{L}^{-1}$ and $400 \mathrm{mg} \mathrm{L}^{-1}$. As the initial growth of the cultures was not restricted by nutrient limitation, the cells did not enter to a lipid-accumulation phase during the course of the fermentation run. Thus, Schizochytrium sp. G13/2S was grown under non $\mathrm{N}$ limiting condition to a high biomass density $\left(60 \mathrm{~g} \mathrm{~L}^{-1}\right)$ in 2 days. The content of total fatty acids in the cells remained constant at about $25 \%(\mathrm{w} / \mathrm{w})$ in which DHA was found near $40 \%$ of the total fatty acids throughout growth; thus DHA and total fatty acids were synthesized entirely growth-associated.

Lipid accumulation in Schizochytrium G13/2S cultured in batch and continuous systems under different $\mathrm{C}$ or $\mathrm{N}$ restrictions and at different dilution rates was studied by Ganuza et al. (2007). Lipid production in batch cultivation of Schizochytrium G13/2S with glucose (40 $\left.\mathrm{g} \mathrm{L}^{-1}\right)$ and glutamate $\left(2 \mathrm{~g} \mathrm{~L}^{-1}\right)$ increased markedly during the late growth phase, reaching about $35 \%$ of DCW. This value was kept constant for the rest of the culture until residual glucose was completely depleted. At the stationary phase, the percentage of DHA in the total fatty acids was between $43-47 \%$. 
Chemostat culture of Schizochytrium G13/2S was conducted using an N limited medium (glutamate $2 \mathrm{~g} \mathrm{~L}^{-1}$ and glucose 40 $\mathrm{g} \mathrm{L}^{-1}$ ) under dilution rates ranging from 0.08 to $0.02 \mathrm{~h}^{-1}$. DCW and the content of total fatty acids increased linearly as dilution rate decreased. The highest biomass (7.7- $6.2 \mathrm{~g} \mathrm{DCW} \mathrm{L}^{-1}$ ) and lipid accumulation (31-28\% TFA) were obtained at the lowest assayed dilution rates (0.02 and $0.04 \mathrm{~h}^{-1}$, respectively).

\section{CONCLUSIONS}

Thraustochytrids as microorganisms for biotechnological production of DHA are current objects of study. At present, most studies focus on the screening for better DHA producer strains. For each new strain, fermentation studies for defining growth medium composition and cultivation techniques need to be carried out in order to improve DHA yield. Although conditions for the production of biomass yields as high as $60 \mathrm{~g} \mathrm{~L}^{-1}$ and DHA yields equal to $15.5 \mathrm{~g} \mathrm{~L}^{-1}$ have been reported, these values could be considered as extraordinary exceptions. As the microbial oil production has to be profitable attempts to reduce production costs are currently tested by different investigators. In this sense, low cost nutrient sources, such as wastewater from the food industry, should be identified. On the other hand, few works present results other than those obtained in flask experiments. The scale-up to higher production levels could offer several challenges due to the high biomass concentration needed in order to increase DHA productivity.

\section{ACKNOWLEDGMENTS}

The authors thank Dirección de Investigación at Universidad de $\mathrm{La}$
Frontera for the economic support provided through Convenios de Desempeño I, II and GAP.

\section{REFERENCES}

Abe, E., Hayashi, Y., Hama, Y., Hayashi, M., Inagaki, M., Ito, M. 2006. A novel phosphatidylcholine which contains pentadecanoic acid at sn-1 and docosahexaenoic acid at sn-2 in Schizochytrium sp. F26-b. J. Biochem. 140, 247-253.

Aki, T., Hachida, K., Yoshinaga, M., Katai, Y., Yamasaki, T., Kawamoto, S., Kakizono, T., Maoka, T., Shigeta, S., Suzuki, O., Ono, K. 2003. Thraustochytrid as a potential source of carotenoids. J. Am. Oil Chem. Soc. 80, 789794.

Bahnweg, G. 1979. Studies on the physiology of Thraustochytriales. II. Carbon nutrition of Thraustochytrium spp., Schizochytrium sp., Japonochytrium sp., Ulkenia spp., and Labyrinthuloides spp., Veröff. Inst. Meeresforsch. Bremerhaven 17, 269-273.

Bajpai, P.K., Bajpai, P., Ward, O.P. 1991. Optimization of production of docosahexaenoic acid (DHA) by Thraustochytrium aureum ATCC 34304. J. Am. Oil Chem. Soc. 68, 509-514.

Barclay, W., Weaver, C., Metz, J. 2005. Development of a DHA production technology using Schizochytrium: a historical perspective. In: Cohen, Z., Ratledge, C. (Eds.), Single Cell Oils, American Oil Chemists' Society, Champaign, IL, USA.

Bowles, R.D., Hunt, A.E., Bremer, G.B., Duchars, M.G. 1999. Long-chain n-3 polyunsaturated fatty acid production by members of the marine protistan group the thraustochytrids: screening of isolates and optimization of docosahexaenoic acid production. J. Biotechnol. 70, 193-202.

Burja, A.M., Radianingtyas, H., Windust, A., Barrow, C.J. 2006. Isolation and characterization of polyunsaturated fatty acid producing Thraustochytrium species: 
screening of strains and optimization of omega-3 production. App. Microbiol. Biotechnol. 72, 1161-1169.

Chamberlain, A.H.L., Moss, S.T. 1988. The thraustochytrids: a protist group with mixed affinities. BioSystems 21, 341-349.

Chi, Z., Pyle, D., Wen, Z., Frear, C., Chen, S. 2007. A laboratory study of producing docosahexaenoic acid from biodiesel-waste glycerol by microalgal fermentation. Process Biochem. 42, 1537-1545.

Fan, K.W., Chen, F., Jones, E.B.G., Vrijmoed, L.L.P. 2001. Eicosapentaenoic and docosahexaenoic acids production by and okara-utilizing potential of thraustochytrids. J. Ind. Microbial. Biotechnol. 27, 199-202.

Fan, K.W., Chen, F. 2007. Production of high-value products by marine microalgae thraustocytrids. In: Yang, S-T. (Ed) Bioprocessing for value-added products from renewable resources. New Technologies and Applications. Amsterdam, Elsevier, pp 293324.

Ganuza, E., Izquierdo, M.S. 2007. Lipid accumulation in Schizochytrium G13/2S produced in continuous culture. Appl. Microbiol. Biotechnol. 270, 985-990.

Ganuza, E., Anderson, A. J., Ratledge, C. 2008. High-cell-density cultivation of Schizochytrium sp. in an ammonium $/ \mathrm{pH}-$ auxostat fed-batch system. Biotechnol. Lett. 30, 1559-1564.

Goldstein, S. 1973. Zoosporic marine fungi (Thraustochytriaceae and Dermocystidiaceae). Annu. Rev. Microbiol. 27, 13-25.

Honda, D., Yokochi, T., Nakahara, T., Raghukumar, S., Nakagiri, A., Schaumann, K., Higashihara, T. 1999. Molecular phylogeny of labyrinthulids and thraustochytrids based on the sequencing of $18 \mathrm{~S}$ ribosomal RNA gene. J. Eukaryot Microbiol. 46, 637-647.

Horrocks, L.A., Yeo, Y.K. 1999. Health benefits of docosahexaenoic acid (DHA). Pharmacol. Res. 40, 211-225.

Huang, J., Aki, T., Yokochi, T., Nakahara, T., Honda, D., Kawamoto, S., Shigeta, S.,
Ono, K., Suzuki, O. 2003. Grouping newly isolated docosahexaenoic acid-producing Thraustochytrids based on their polyunsaturated fatty acid profiles and comparative analysis of 18S rRNA genes. Mar. Biotechnol. 5, 450-457.

Iwamoto, H., Sato, G. 1986. Production of EPA by freshwater unicellular algae. J. Am. Oil Chem. Soc. 63, 434-438.

Jain, R., Raghukumar, S., Sambaiah, K., Kumon, Y., Nakahara, K. 2007. Docosahexaenoic acid accumulation in thraustochytrids: search for rationale. Mar. Biol. 151, 1657-1664.

Jain, R., Raghukumar, S., Tharanathan, R., Bhosle, N.B. 2005. Extracellular polysaccharide production by thraustochytrid protists. Mar. Biotechnol. 7, 184-192.

Jiang, Y., Fan, K-W., Wong, R.T-Y, Chen, F. 2004. Fatty acid composition and squalene content of the marine microalga Schizochytrium mangrovei. J. Agric. Food Chem. 52, 1196-1200.

Kiy, T., Rusing, M., Fabritius, D. 2005. Production of docosahexaenoic acid (DHA) by the marine microalga, Ulkenia sp. In: Cohen, Z., Ratledge, C. (Eds.), Single Cell Oils, American Oil Chemists' Society, Champaign, IL, USA.

Leipe, D.D., Wainright, P.O., Gunderson, J.H., Porter, D., Patterson, D.J., Valois, F., Himmerich, S., Sogin, M.L. 1994. The stramenopiles from a molecular perspective: 16S-like rRNA sequences from Labyrinthuloides minuta and Cafeteria roenbergensis. Phycologia 33, 369-377.

Ma, C.Y., Liu, W.S., Kwok, K.C., Kowk, F. 1997. Isolation and characterization of proteins from soymilk residue (okara). Food Res. Int. 29, 799-805.

Morita, E., Kumon, Y., Nakahara, T., Kagiwada, S., Noguchi, T. 2006. Docosahexaenoic acid production and lipidbody formation in Schizochytrium limacinum SR21. Mar. Biotechnol. 8, 319-327.

Nichols, D.S., Nichols, P.D., McMeekin, T.A. 1993. Polyunsaturated fatty acids in antarctic bacteria. Antarct Sci. 5, 149-160. 
Nichols, D.S., Sanderson, K., Buia, A., Van de Kamp, J., Holloway, P., Bowman, J.P., Smith, M., Cancuso, C., Nichols, P., Nichols, D., McMeekin, T.A. 2002. Bioprospecting and Biotechnology in Antarctica. In: JabourGreen, J., Haward, M. (Eds.) The Antarctic: Past, Present and Future. Antarctic CRC Research Report \#28, Hobart, pp 85-103.

Okuyama, H., Orikasa, Y., Nishida, T. 2007. In vivo conversion of triacylglycerol to docosahexaenoic acid-containing phospholipids in a thraustochytrid-like microorganism, strain 12B. Biotechnol. Lett. 29, 1977-1981.

Porter, D. 1989. Phylum Labyrinthulomycota. In: Margulis. L., Corlis, J.O., Melconian, M., Chapman, D.J, (Eds.) Handbook of Protoctista. Jones and Bartlett, Boston, pp 388-398.

Quilodrán, B. Hinzpeter, I., Quiroz, A., Shene, C. 2009. Evaluation of liquid residues from beer and potato processing for the production of docosahexaenoic acid (C22:6n3 , DHA) by native thraustochytrid strains. World J. Microbiol. Biotechnol. 21, 21212128.

Quilodrán, B. Hinzpeter, I. Hormazabal, E. Quiroz, A. Shene, C. 2010. Docosahexaenoic acid (C22:6n-3, DHA) and astaxanthin production by Thraustochytriidae sp. AS4-A1 a native strain with high similitude to Ulkenia sp.: Evaluation of liquid residues from food industry as nutrient sources. Enzyme Microb. Technol. 47, 24-30.

Ratledge, C., Wynn, J.P. 2002. The biochemistry and molecular biology of lipid accumulation in oleaginous microorganisms. Adv. Appl. Microbiol. 51, 1-51.

Singh, A., Ward, O.P. 1996. Production of high yields of docosahexaenoic acid by Thraustochytrium roseum ATCC 28210. J. Ind. Microbiol. 16, 370-373.

Unagul, P., Assantachai, $\quad$ C., Phadungruengluij, S., Suphantharika, M., Tanticharoen, M., Verduyn, V. 2007. Coconut water as a medium additive for the production of docosahexaenoic acid (C22:6 n3) by Schizochytrium mangrovei Sk-02. Bioresource Technol. 98, 281-287.
Yaguchi, T., Tanaka, S., Yokochi, T., Nakahara, T., Higashihara, T. 1997. Production of high yields of docosahexaenoic acid by Schizochytrium sp. strain SR21. J. Am. Oil. Chem. Soc. 74, 1431-1434.

Yamasaki, T., Aki, T., Shinozaki, M., Taguchi, M., Kawamoto, S., Ono, K. 2006. Utilization of shochu distillery wastewater for production of polyunsaturated fatty acids and xanthophylls using thraustochytrid. J. Biosci. Bioeng. 102, 323-327.

Yokochi, T., Honda, D., Nakahara, T. 1998. Optimization of docosahexaenoic acid production by Schizochutrium limacinum SR21. Appl. Microbol. Biotechnol. 49, 72-76.

Yokoyama, R. Honda, D. 2007. Taxonomic rearrangement of the genus Schizochytrium sensu lato based on morphology, chemotaxonomical characteristics and $18 \mathrm{~S}$ rRNA gene phylogeny (Thraustochytriaceae, Labyrinthulomycetes, stramenopiles): emendation for Schizochytrium and erection of Aurantiochytrium and Oblongichytrium gen. nov. Mycoscience 48, 199-211.

Yokoyama, R., Salleh, B., Honda, D. 2007. Taxonomic rearrangement of the genus Ulkenia sensu lato based on morphology, chemotaxonomical characteristics, and $18 \mathrm{~S}$ rRNA gene phylogeny (Thraustochytriaceae, Labyrinthulomycetes): emendation for Ulkenia and erection of Botryochytrium, Parietichytrium, and Sicyoidochytrium gen nov. Mycoscience 48, 329-341.

Zhu, L., Zhang, X., Ren, X., Zhu, Q. 2008. Effects of culture conditions on growth and docosahexaenoic acid production from Schizochytrium limacinum. J. Ocean Univ. Chin. (Oceanic and Coastal Sea Research) 7, 83-88. 